\title{
Adaptation of Root Crop Farming System to Climate Change in Ikwerre Local Government Area of Rivers State, Nigeria
}

\author{
Vincent Ezikornwor Weli' ${ }^{*}$, Samba Bajie ${ }^{2}$ \\ ${ }^{1}$ Department of Geography and Environmental Management, Faculty of Social Sciences, University of Port Harcourt, Port \\ Harcourt, Nigeria \\ ${ }^{2}$ Deputy Ombudsman, Banjul, Gambia \\ Email: ^welivinezi@yahoo.com, sbajie2012@gmail.com
}

How to cite this paper: Weli, V.E. and Bajie, S. (2017) Adaptation of Root Crop Farming System to Climate Change in Ikwerre Local Government Area of Rivers State, Nigeria. American Journal of Climate Change, 6, 40-51.

https://doi.org/10.4236/ajcc.2017.61003

Received: February 17, 2016

Accepted: February 6, 2017

Published: February 9, 2017

Copyright $\odot 2017$ by authors and Scientific Research Publishing Inc. This work is licensed under the Creative Commons Attribution International License (CC BY 4.0).

http://creativecommons.org/licenses/by/4.0/

\begin{abstract}
This study examined adaptation of root crop farming system to climate change in Ikwerre Local Government Area of Rivers state, Nigeria. Seven towns were selected based on a population of five thousand and above from which one hundred and ninety-one respondents were randomly chosen. Sixty-six years' data on climatic variables of rainfall, temperature and relative humidity were obtained from Nigeria Meteorological Agency between 1950-2015. Analyses were carried out using simple proportion for qualitative variables while mean and standard deviation were used in analyzing the qualitative variable. Similarly, the triangulation method involving qualitative and quantitative components in data generation was used. Results showed that, there had been a steady but gradual increase in the mean annual minimum and maximum temperatures over the study period of thirty years. The overall mean rainfall computed was $191.1 \mathrm{~mm}$. In general, there was a shift increase in both rainfall and temperature during the period under study. The respondents attributed crop failure (100\%), reduced crop yield (100\%), increase incidence of pest and diseases (100\%) and delay in planting period (100\%) as direct effects of climate change. A steady trend in relative humidity of (84.3\%) was recorded and the mean annual wind speed computed was 67.9 knots. The adapted strategies include delay planting period, crop diversification $100 \%$, cultivation of early maturing crops such as maize, vegetables, intercropped with the root crops and changes in the time of farm operations $(99.4 \%)$ as well as a change in the planting period and changing farm location (98.9\%). The latter will in addition to other benefits reduce the incidences of pest and diseases that may be attracted to the same field if continuously cultivated with the same crops. An implementable policy of accessibility of finance to the real farmers is seriously advocated.
\end{abstract}




\section{Keywords}

Root Crop, Climate Change, Adaptation, Farming System and Crop Failure

\section{Introduction}

Agricultural production remains the main source of livelihood for most rural communities in Nigeria. It provides a source of employment for more than $60 \%$ of the population and contributes about $30 \%$ of Gross Domestic Product (GDP) [1]. The performance of the agricultural sector is determined by crop production, which depends on a large number of both edaphic and climatic factors such as endowment of soils, rainfall, temperature, and relative humidity. But recent concerns and findings indicate that these climatic variables are changing. Climate change refers to any variation in climate over time, whether due to natural variability or as a result of human activity [2] [3]. Climate change in the form of higher temperatures, reduced rainfall and increased rainfall variability, reduces crop yields and net farm revenues and threatens food security in low income based economies including African countries [4] [5]. At the 10th and 38th Session of Inter-Governmental Panel on Climate Change (IPCC) Working Group II in Yokohama, Japan, the world is warned that climate change's impacts are leading to shifts in crop yields, overall decrease in yields, with the likelihood that global average surface temperature rising to 1.8 degrees to 4.0 degrees Celsius by 2100. Climate variability will increase almost everywhere. Northern latitudes will experience more rainfall; many subtropical regions will see less. In light of these, some indigenous communities are changing seasonal migration and hunting patterns to adapt to changes in temperature [6]. Furthermore, IPCC report [7] predicts that the climate change over the next century will affect rainfall pattern, river flows and sea levels all over the world. Studies show that agricultural yield will likely be severely affected over the next hundred years due to unprecedented rates of changes in the climate system [8] [9]. The accelerated increase in the greenhouse gases (GHG), concentration in the atmosphere is a major cause for climate change. Studies such as [10] [11], predict that by the year 2050, the rainfall in Sub-Saharan Africa (Nigeria inclusive) could drop by $10 \%$, which will cause a major water shortage. This $10 \%$ decrease in precipitation would reduce drainage by $17 \%$ and the regions which are receiving $500-600 \mathrm{~mm} /$ year rainfall will experience a reduction by $50 \%-30 \%$ respectively in the surface drainage. This has serious implications for Nigeria which is by far the world's largest producer of yams, accounting for over 70 - 76 percent of the world production. According to the Food and Agricultural Organization report in 1985, Nigeria produced 18.3 million tons of yams from 1.5 million hectares, representing 73.8 percent of total yam production in Africa. According to 2008 figures, yam production in Nigeria has nearly doubled since 1985, with Nigeria producing 35.017 million metric tons with value equivalent of US $\$ 5.654$ billion. Considering the 
findings above, there is need to preserve, boost and promote the agricultural sector especially root crop farming system as an alternative means of income for the Nigerian economy to cushion the economic shocks experienced by the fluctuating global oil prices in the face of the current economic recession. [12] investigated remote sensor technology for precision crop production. The findings of the study revealed that a combination of items was needed by farmers in utilizing sensory technology for precision crop production. [13] examined climate change impacts and adaptation in rain-fed farming system using a modelling framework for scaling out climate smart agriculture. The potential for improving soil water productivity and improved water harvesting have been explored as ways of climate change mitigation and adaptation measures. The paper argued that this can be utilized to explore and design appropriate conservation agriculture and adaptation practices in similar agro-ecological environments, and create opportunities for out-scaling for much wider areas. [14] studied the impact of climate change on yields for the four most commonly grown crops (millet, maize, sorghum and cassava) in Sub-Saharan Africa (SSA). A panel data approach was used to relate yields to standard weather variables, such as temperature and precipitation, and sophisticated weather measures, such as evapotranspiration and the standardized precipitation index (SPI). Each GCM was simulated under a range of greenhouse gas emissions (GHG) assumptions. Relative to a case without climate change, yield changes in 2100 are near zero for cassava and range from $-19 \%$ to $+6 \%$ for maize, from $-38 \%$ to $-13 \%$ for millet and from $-47 \%$ to $-7 \%$ for sorghum under alternative climate change scenarios. [15] examined Farmers' Perceptions of and Adaptations to Climate Change and Variability in Togo. The results highlight that education level, farming experience, access extension services, access to credit and access to climate information are the factors that enhance farmers' adaptive capacity to climate change and variability. [16] analyzed of Climate Variability, Perceptions and Coping Strategies of Tanzanian Coastal Forest Dependent Communities. Findings showed that households primarily attribute reduced crop yields to changes in rainfall pattern and increasing incidences of drought leading to soil moisture stress. The implications are that the agriculture dependent households are now food insecure. As a way of coping to the observed changes, the coastal communities among others have shifted to production of high value horticultural crops and use of forest resources. Haven reviewed some of the related studies; this paper however, is a novel study in the locale and most especially, its impact on root crops that is predominantly planted by all the farmers in the area. However, most studies carried out in Nigeria were on Cassava only. No known study has examined a combination of different root crops such as cassava, yams, sweet potatoes and cocoa yam in relation to adaptation to climate change especially in a mostly agrarian Ikwerre Local Government Area of Rivers state, Nigeria. The experience of farmers in the area which includes crop failure, reduced crop yield, increase incidence of pest and diseases and delay in planting period, change in farming location as direct effects of climate change were specific to the study locale different 
from other related studies in the literature. More so, adaptation varies from location to location because of the peculiar nature of each study locale and the crop that is involved. This study is contributing to the literature of the knowledge of adaptation to climate change from Nigeria especially on root crops which is different from the study already published in the literature from around the world.

The challenges pose by climatic variations on crop production has also been well documented (see [17]-[23]). These authors reported that climate change will likely lead to a major spatial shift and extension of crop lands as it will create a favorable or restricted environment for crop growth across different regions. And that frequency of heat stress; drought and flood negatively affect crop production. However, the studies cited above were carried out mostly on cassava in different parts of Nigeria. No known study has examined a combination of different root crops such as cassava, yams, sweet potatoes and cocoa yam in relation to adaptation to climate change especially in a mostly agrarian Ikwerre Local Government Area of Rivers state, Nigeria. This is the gap in knowledge which this study intends to provide. This study seeks to investigate the adaptation of root crop farming system on climate change to compliment knowledge in the literature of the problem. Principally the study is set out to find out how farmers in the area have coped with the impacts of climate change and identify their adaptation strategies on cassava, yam, cocoa yam and sweet potatoes production over the decades. It equally identified the root crops that are predominantly impacted by the changing climate.

\section{Geography of the Study Area}

Ikwerre Local Government Area is one of the 23 LGAs in Rivers State. It has a population of 188,930 (male and female), Rivers State Population census, 2006. Total annual rainfall decreases from about $4,700 \mathrm{~mm}$ on the coast to about 1,700 $\mathrm{mm}$ in extreme north of the State. Rainfall is adequate for all year round crop production in the State. The mean monthly temperature is in the range of 25 to $28^{\circ} \mathrm{C}$. The main root crops are yam, cassava and cocoyam; while the grains are maize, lowland rice and beans. Other crops grown for food include vegetables, melon, pineapples and plantain. The major cash crops are oil palm products, rubber, coconut, raffia palm and jute.

\section{Methodology}

The study used the mixed methods (triangulation) involving qualitative and quantitative components. Two sets of data were used namely the primary data and secondary data. The primary data was obtained through questionnaire administration on farmers understanding of climate change, its effects on root crop production and their adaptation strategies to the production and productivity of their root crops. The qualitative methodology involved focused group discussions and consultations with individual interviews of local farmers including females. The second set of data, the secondary data was collected from Federal Meteorological Agency Port Harcourt, Rivers State on four climate variables 
namely: Rainfall, Temperature, Relative Humidity and Wind speed over a period of sixty-six years for analysis. To achieve the objective of the study seven town were selected based on a population of five thousand and above in the area for analysis. These are Omuawa, Uzuaha, Omagwa, Obodo-Isiokpo, Omademe, Ubima and Omodukwu-Igwuruta. A total of one hundred and nineteen (119) structured questionnaires were developed and thirty percentage $(30 \%)$ of the root crop farmers (young and old), were randomly selected in each of the seven sampled community for interviewing. Questionnaires were distributed to educated farmers young and old, or who had educated relatives in their compounds after thorough explanations of the aim and objectives of the study to the respondents through an interpreter. The implication of including the younger farmers is that younger farmers are likely to adopt new innovation faster than the older ones. This is in agreement with [24] that majority of farmers within the age range of 41 to 50 years are still in their active age, more receptive to innovation and could withstand the stress and strain involved in agricultural production and ease adaptation to climate change.

Data analysis was carried out using simple proportion for qualitative variables while mean and standard deviation were used in analyzing the qualitative variable. The outputs were further presented in tables and charts. The data was structured and presented from the responses to the research questions in line with the aim and objectives of the study. The analysis of the data both primary and secondary data was aimed at bringing to the knowledge of both informed and uninformed stakeholders, the basic understanding, adaptive strategies and experiences of climate change and its effects on root crop farming system in the sampled communities of the Ikwerre Local Government Area, of Rivers State, Nigeria.

\section{Results and Discussion of Findings}

\subsection{Demographic Characteristics of Farmers in the Locality}

Of the sampled population of 179 respondents in all the seven communities of Ikwerre local government area, there were 78.8 percent male respondents and 21.2 percent female respondents. The age distribution of respondents showed that farmers were between the age brackets $36-50$ yrs (43.6\%), was the highest in the age distribution followed by 26 - 35 yrs (21.2\%), 51 - 65 yrs (20.7\%), 15 25 (8.4\%) and $\geq 65$ yrs (6.1\%). The result of years of farming experience by age in the study area showed that farmers with 10 - 19 years (39.7\%), of farming experience were the highest respondents, however this can be explained by the fact that most of the farmers met during the study were middle aged farmers with few farmers within the ages of 51 and above. This is followed by farmers with 20 - 29 years (22.3\%), farming experience who were very close to having the threedecade farming experiences upon which the effects of Climate variables were measured. Farmers with 0 - 9 years $(9.5 \%)$, were third in the rank followed by farmers with 0 - 49 years farming experience $(6.7 \%)$ and those with $>50$ years were bottom on the list representing $(0.6 \%)$, of the sampled respondents. Below, 
however, is the analysis of farm size according to sampled communities.

\subsection{Climate Characteristics of the Study Area}

The Climate characteristics showed mean annual pattern of rainfall and temperature in Ikwerre LGA from 1950-2015. Ikwerre LGA had an annual mean rainfall of $2375 \mathrm{~mm}$ that spans $1475 \mathrm{~mm}$ in 1951 to $3056 \mathrm{~mm}$ in 2012. This showed an increase of $1581 \mathrm{~mm}$ over the years (See Weli and Efe, 2014). The polynomial trendline show an increase in rainfall over the years, with $0.61 \mathrm{R}^{2}$ value and showed an increase of $1581 \mathrm{~mm}$ from 1950-2015. Findings indicated that, Ikwerre LGA had experienced a rise of $3^{\circ} \mathrm{C}$ in temperature $\left(25^{\circ} \mathrm{C}-28^{\circ} \mathrm{C}\right)$ from $1950-2015$, with $27.2^{\circ} \mathrm{C}$ mean annual temperature distribution. The temperature polynomial trend line showed a rise in temperature with $\mathrm{R}^{2}$ value of 0.15 . The flow pattern of rainfall and temperature followed an inverse pattern, indicating that temperature decreases with an increase in rainfall in the area. This corroborated [25] [26] [27] findings showed that the normal period of rainfall showed a u-shape, indicating a decrease in rainfall from $2693 \mathrm{~mm}$ (1950-1979) to $2316 \mathrm{~mm}$ (1980-2009), thereafter a rise to $2670 \mathrm{~mm}$ in 2010-2015, this showed that while 1950-1979 and 2010 till date are wetter epoch, 1980-2009 is the driest periods. This is an evidence of climate change in Ikwerre LGA with $\mathrm{R}$ value of 1 , and the polynomial trend line revealed that increase in rainfall correlated perfectly with increase in years. Similarly, there was a gradual rise in temperature from 1950-2015; this was evident with temperature values of $26.9^{\circ} \mathrm{C}, 27.4^{\circ} \mathrm{C}$ and $27.5^{\circ} \mathrm{C}$ for three epochs (1950-1979, 1980-2009 and 2010-2015). And the linear trend line exhibited a rise in temperature which correlated strongly with increase in years with $\mathrm{R}$ value of 0.94 . This trend pattern of rainfall and temperature is an evidence of climate change in the study area. This is confirmed with a decrease of $377 \mathrm{~mm}$ in rainfall from the first epoch (1950-1979), and an increase of $354 \mathrm{~mm}$ from the second epoch (1980-2009) to the last epoch (2010-2015). This had triggered flood hazards in the area. The farmers also attested that flood was the only climate related hazard which affects the root crops cultivation. Temperature on the other hand had a rise of $0.5^{\circ} \mathrm{C}$ from the first epoch (1950-1979) to the second epoch (1980-2009), and a rise of $0.1^{\circ} \mathrm{C}$ from the second epoch to the third epoch (2010-2015).

The decadal rainfall pattern indicated that the period 1950-1959 and 1960-1969 had an increase in rainfall with $209.4 \mathrm{~mm}$ and $421.3 \mathrm{~mm}$ respectively, thereafter, there is a decrease of $438.3 \mathrm{~mm}$ from 1970-1979. Nevertheless, 1980-1989 and 1990-1999 also recorded wetter periods of $19.6 \mathrm{~mm}$ to $112.9 \mathrm{~mm}$ rainfall, and a decrease of $70.3 \mathrm{~mm}$ was recorded from 2000-2009. And the period 2010-2015 had an increase of $363.7 \mathrm{~mm}$ which often exacerbate ecological hazards in the area. The polynomial trendline of rainfall anomalies showed a clearer trend pattern of gradual decrease from 1950-1985, thereafter, there was a gradual increase in rainfall till date (Figure 1), indicating a change in the rainfall sequence of Port Harcourt for the period 1950 till date.

Result showed that the temperature pattern had two epochs of $27.4^{\circ} \mathrm{C}$, and $27.5^{\circ} \mathrm{C}$ for $1950-1969,1980-189,2000-2009$ and 2010 till date. This period had a 
temperature rise of $0.9^{\circ} \mathrm{C}, 0.4^{\circ} \mathrm{C}, 0.05^{\circ} \mathrm{C}$ and $0.14^{\circ} \mathrm{C}$ respectively, indicating a change in temperature. From Figure 1, the linear trend line of temperature anomalies showed a gradual rise in temperature from 1955 till date which showed that Port Harcourt is warmer in the last two decades than the previous years. However, the first decade is cooler than other decades.

\subsection{Physical Characteristics, Challenges and Climate Events Significantly Impacting Root Crop Farming}

Table 1 shows farm size (local measure, plots) of the sampled farmers in all seven communities. The table indicates that out of the entire sampled population, farmers with 0 - 4 farm plots (46.4\%), (local measure), have the highest percentage followed by those with farm plots ranging between 5 - 9 farm plots (33.0\%), 10 - 14 farm plots (19.6\%) and 15 - 19 farm plots and 20 farm plots and above respectively recording $(0.6 \%)$, indicating the subsistence nature of root crop production in the Ikwerre local government area which is a characteristic farming system for most food crops in sub Saharan Africa and Nigeria is no exception.

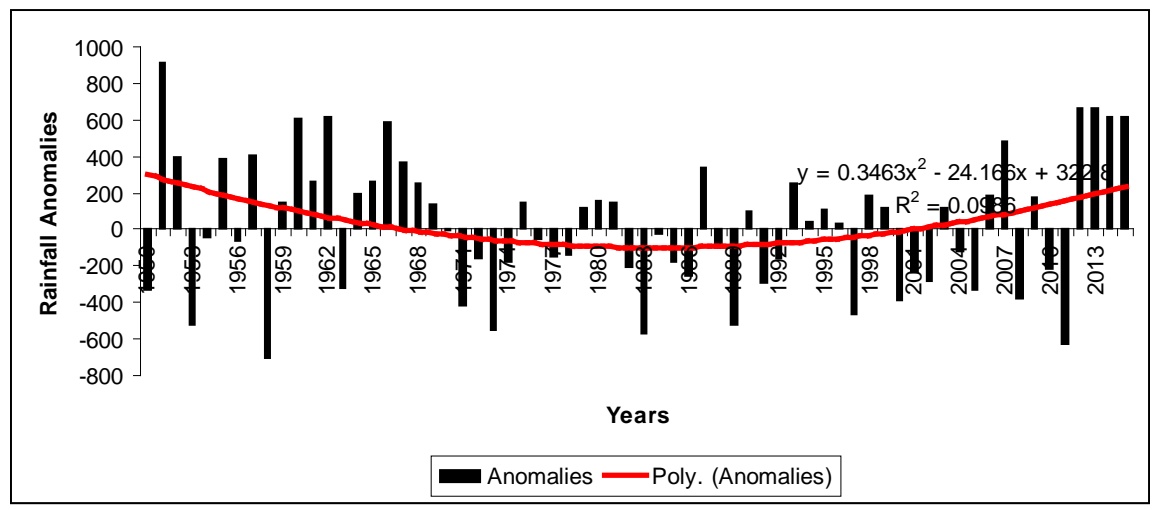

Figure 1. Rainfall anomalies 1950-2015.

Table 1. Mean ranking and standard deviation of the challenges encounter by farmers in the sampled communities.

\begin{tabular}{lcc}
\hline \multicolumn{1}{c}{ Constraints } & Mean & Std. dev. \\
\hline Access to funding & 2.989 & 0.011 \\
Access to technological information & 2.944 & 0.053 \\
Fluctuation in price & 2.933 & 0.063 \\
Access to extension services & 2.894 & 0.117 \\
Cost of labour & 2.888 & 0.099 \\
Cost of cultivation & 2.816 & 0.184 \\
Pest and disease incidence & 2.039 & 0.172 \\
Availability of storage facilities & 1.922 & 0.240 \\
Inadequate farm size & 1.156 & 0.132 \\
Availability of quality seeds & 1.017 & 0.028 \\
Competition for land between Male \& Female & 1.006 & 0.006 \\
Access to market & 1.000 & 0.000 \\
Source of irrigation & 1.000 & 0.000 \\
\hline
\end{tabular}


Findings indicates in Table 1 that access to funding is highest in the farmer's priorities with a mean of 2.989 and for the farmers to be able to acquire modern farming tools and equipment to improve their farming activities; access to funding is a vital necessity for every subsistence farmer. Next on their priority ranking according to their responses, is the access to technological information with a mean of 2.944 which inevitably is an uncompromising requirement for farmers especially for those in the developing countries like Africa. The study revealed the missing link between research and the farmers through their responses on inaccessibility to extension services indicated by a mean value of 2.984. Other are cost of cultivation (2.816), pest and disease incidence (2.039), availability of storage facilities (1.922); inadequate farm size (1.156), availability of quality seeds (1.017); competition for land between Male \& Female (1.006), access to market (1.000) and source of irrigation (1.000). It was clear that the local inhabitants depend on rain-fed agriculture for their crops. This makes farming in the area highly vulnerable to climate change.

Table 2 showed results of Major Climate events that had significantly affected farm production in percentage (\%). From the 179 respondents from the seven sampled communities in the Ikwerre local government area, $99.4 \%$ claimed that flood is their major climatic event that significantly affected their farm production.

Table 2 shows results of the Effect of climate-related events on root crop production (\%). The results revealed that Crop failure, reduced crop yields and delay in planting period are the major resultant effects of climate-related events on root crop production representing $100 \%$ of sampled farmer's opinions followed by incidence of pests and diseases which came out high on their observations on the effects of climate related events scoring 99.4\% from the entire sampled population of 179 respondents. The study attributes crop failure, reduced crop yield, increase incidence of pest and diseases and delay in planting period are the direct effect of climate variables.

Table 3 shows results of farmer's adaptive strategies to the effects of climate change in a bid to avoid total income and crop failure from their farming activities as follows: delay planting period, crop diversification $100 \%$. Cultivation of early maturing crops such as maize, vegetables intercropped with the root crops and changes in the time of farm operations $99.4 \%$ respectively as well as the

Table 2. Effect of climate-related events on root crop production (\%).

\begin{tabular}{|c|c|c|c|c|c|c|c|c|}
\hline \multirow{2}{*}{$\begin{array}{c}\text { Effect of } \\
\text { climate-related } \\
\text { event }\end{array}$} & \multicolumn{8}{|c|}{ Proportion of respondents (\%) } \\
\hline & Omuanwa & Ozuaha & Omagwa & ObodoIsiokpo & Omademe & Ubima & OmodukwuIgwuruta & General opinion \\
\hline Crop failure & 100.0 & 100.0 & 100.0 & 100.0 & 100.0 & 100.0 & 100.0 & 100.0 \\
\hline Reduced crop yield & 100.0 & 100.0 & 100.0 & 100.0 & 100.0 & 100.0 & 100.0 & 100.0 \\
\hline $\begin{array}{l}\text { Increased incidence } \\
\text { of pest and diseases }\end{array}$ & 100.0 & 96.6 & 100.0 & 100.0 & 100.0 & 100.0 & 100.0 & 99.4 \\
\hline Delay in planting period & 100.0 & 100.0 & 100.0 & 100.0 & 100.0 & 100.0 & 100.0 & 100.0 \\
\hline
\end{tabular}


Table 3. Adaptation strategies to reduce the negative effects of the climate related events (\%).

\begin{tabular}{|c|c|c|c|c|c|c|c|c|}
\hline \multirow{2}{*}{$\begin{array}{c}\text { Adaptation Strategies } \\
\text { adopted }\end{array}$} & \multicolumn{8}{|c|}{ Proportion of respondents (\%) } \\
\hline & Omuanwa & Ozuaha & Omagwa & ObodoIsiokpo & Omademe & Ubima & Omodukwuigwuruta & Total \\
\hline $\begin{array}{l}\text { Planting of drought-resistant } \\
\text { varieties }\end{array}$ & 0.0 & 0.0 & 0.0 & 0.0 & 0.0 & 0.0 & 0.0 & 0.0 \\
\hline $\begin{array}{l}\text { Cultivation of early } \\
\text { maturing crops }\end{array}$ & 100.0 & 96.6 & 100.0 & 100.0 & 100.0 & 100.0 & 100.0 & 99.4 \\
\hline $\begin{array}{l}\text { Changes in time of farm } \\
\text { operation }\end{array}$ & 100.0 & 96.6 & 100.0 & 100.0 & 100.0 & 100.0 & 100.0 & 99.4 \\
\hline Rain water harvesting & 0.0 & 0.0 & 0.0 & 0.0 & 0.0 & 0.0 & 0.0 & 0.0 \\
\hline $\begin{array}{l}\text { Access to agricultural } \\
\text { extension services }\end{array}$ & 0.0 & 3.4 & 0.0 & 0.0 & 0.0 & 0.0 & 0.0 & 0.6 \\
\hline $\begin{array}{l}\text { Contacting agricultural } \\
\text { extension services }\end{array}$ & 0.0 & 0.0 & 0.0 & 0.0 & 0.0 & 0.0 & 0.0 & 0.0 \\
\hline $\begin{array}{l}\text { Crop diversification } \\
\text { (intercropping) }\end{array}$ & 100.0 & 100.0 & 100.0 & 100.0 & 100.0 & 100.0 & 100.0 & 100.0 \\
\hline Use of windbreaks & 0.0 & 0.0 & 0.0 & 0.0 & 0.0 & 0.0 & 0.0 & 0.0 \\
\hline Change of farm location & 100.0 & 93.1 & 100.0 & 100.0 & 100.0 & 100.0 & 100.0 & 98.9 \\
\hline
\end{tabular}

planting period to avoid crop failure and changing their farm location $98.9 \%$. The latter will in addition to other benefits reduce the incidences of pest and diseases that may be attracted to the same field if continuously cultivated with the same crops.

Analysis of how farmers adjusted to long-term shifts in two major climatic variables that affected root crop farming revealed that apart from Ozuaha (96.6\%) all the other six communities indicated $100 \%$ wait for a favorable period before planting during a long-term shift in rainfall and replanting of crops that died off during long-term shifts in temperature. However, in Ozuaha, 3.4\% will plant at their usual planting periods during long-term shifts in rainfall. But during long-term shifts in temperature, $96.6 \%$ of the farmer's reported that they replanted those crops that died off and $3.4 \%$ do not replant.

Findings further showed that the four major root crops cultivated include sweet potatoes, cocoa yam, yams and cassava. Amongst these four major root crops, cassava is the most widely root crop (indicating 100\%) cultivated, meaning that each sampled farmer cultivates cassava followed by yam (98.9\%), cocoa yam $(10.1 \%)$ and sweet potatoes $(7.8 \%)$. It therefore, showed that cassava was the mostly affected root crops by climate change especially the changes in rainfall and temperature.

\section{Conclusion}

The study area has passed through a steady but gradual increase in the means of annual rainfall $(191.1 \mathrm{~mm})$, minimum $\left(22.7^{\circ} \mathrm{C}\right)$, and maximum temperatures $\left(31.5^{\circ} \mathrm{C}\right)$, over the study period of sixty years (1950-2015). The farmers similarly attributed crop failure, reduced crop yield, increased incidence of pest and dis- 
eases and delay in planting period as the direct effects of climate change. Adaptation techniques by the farmers include crop diversification, cultivation of early maturing crops such as maize, vegetables intercropped with the root crops and changes in the time of farm operations. Others include changing farm location as well as delaying planting period.

\section{Recommendation}

In view of the above findings and the growing concerns of climate change, the study posits the need for Climate Smart Agricultural (CSA) practices which would reduce GHG emissions and their effects while increasing crop yield. The following specific adaptation strategies are recommended for sustainable root crop cultivation.

1) Farmer cooperatives need to be promoted for easy access of funding to farmers to boost their crop production;

2) Media outlets such as radio stations, television stations, print media, comedians, etc., should be exploited to relay messages to the remotest farmer on new technologies and any agricultural information;

3) Climate information should be relayed to farmers in languages they understand best such as weather forecasts, early warning systems, etc.;

4) Establish agro based industries to add value to root crops thereby creating the opportunity to increase farmer's income;

5) Enhance community's resilience strategies, including adopting appropriate technologies, diversifying their livelihoods to cope with current and future climate stress;

6) Use of local coping strategies and traditional knowledge in synergy with government interventions through policies;

7) Promote crop diversification, integrated pest management and crop insurance.

\section{References}

[1] Kandlinkar, M. and Risbey, J. (2000) Agricultural Impacts of Climate Change. If Adaptation Is the Answer, What Is the Question? Climate Change, 45, 529-539. https://doi.org/10.1023/A:1005546716266

[2] IPCC (2001) Climate Change 2001: The Scientific Basis. Contribution of Working Group I to the Third Assessment Report of the Intergovernmental Panel on Climate Change. Cambridge University Press, Cambridge.

[3] IPCC (2001) Climate Change 2001: Impacts, Adaptation, and Vulnerability. Contribution of Working Group II to the Third Assessment Report of the 447 Intergovernmental Panel on Climate Change. Cambridge University Press, Cambridge.

[4] FAO (2007) Climate Change and Food Security. FAO, Rome.

[5] TerrAfrica (2009) Advancing Sustainable Land Management in Sub-Saharan Africa Our Land, Our Wealth, Our Future, Our Hands TerrAfrica Annual Report. New Partnership for Africa's Development (NEPAD).

[6] IPCC (2014) Climate Change 2014: Impacts, Adaptation, and Vulnerability. IPCC WGII AR5 Volume FAQs Based on the 10th Session of Working Group II 
(WGII-10).

http://ipcc-wg2.gov/AR5/images/uploads/WGIIAR5-Volume-FAQs_FGD.pdf

[7] IPCC (2008) Climate Change and Water. Intergovernmental Panel on Climate Change Technical Paper VI, WMO.

[8] Jarvis, A., Upadhaya, H., Gowda, C.L.L., Aggarwal, P.K., Fujisaka, S. and Anderson, B. (2010) Climate Change and Its Effect on Conservation and Use of Plant Genetic Resources for Food and Agriculture and Associated Biodiversity for Food Security. Thematic Background Study. The Second Report on the State of the World's Plant Genetic Resources for Food and Agriculture, Food and Agriculture Organization of the United Nations, Rome.

[9] Thornton, P.H., Jones, P.G., Ericksen, P.J. and Challinor, A.J. (2011) Agriculture and Food Systems in Sub-Saharan Africa in a $4^{\circ} \mathrm{C}+$ World. Philosophical Transactions of the Royal Society A, 369, 117-136. https://doi.org/10.1098/rsta.2010.0246

[10] Nyong, A. (2005) Abstract in Impacts of Climate Change in the Tropics: The African Experience. Avoiding Dangerous Climate Change, Meteorological Office, Exeter. www.stabilisation2005.com

[11] Stankiewicz, J. and de Wit, M. (2006) Changes in Surface Water Supply across Africa with Predicted Climate Change. Science, 311, 1917-1921. https://doi.org/10.1126/science.1119929

[12] Jarvis, A., Ramirez-Villegas, J., Herrera Campo, B.V. and Navarro-Racines, C. (2012) Is Cassava the Answer to African Climate Change Adaptation? Tropical Plant Biology, 5, 9-29. https://doi.org/10.1007/s12042-012-9096-7

[13] Berhanu, F.A. and Simalenga, T. (2015) Climate Change Impacts and Adaptation in Rainfed Farming Systems: A Modeling Framework for Scaling-Out Climate Smart Agriculture in Sub-Saharan Africa. American Journal of Climate Change, 4, 313329. https://doi.org/10.4236/ajcc.2015.44025

[14] Ayindea, O.E., Muchiea, M. and Olatunjib, G.B. (2011) Effect of Climate Change on Agricultural Productivity in Nigeria; A Co-Integration Model Approach. Journal of Human Ecology, 35, 189-194.

[15] Richard, Y., Fauchereau, N., Poccard, I., Rouault, M. and Trzaska, S. (2001) 20th Century Droughts in Southern Africa: Spatial and Temporal Variability, Teleconnections with Oceanic and Atmospheric Conditions. International Journal of Climatology, 21, 873-885. https://doi.org/10.1002/joc.656

[16] Kashaigili, J.J., Levira, P., Liwenga, E. and Mdemu, M.V. (2014) Analysis of Climate Variability, Perceptions and Coping Strategies of Tanzanian Coastal Forest Dependent Communities. American Journal of Climate Change, 3, 212-222. https://doi.org/10.4236/ajcc.2014.32020

[17] Olaniran, O.J. (1991) Evidence of Climate Change in Nigeria Based on Annual Series of Rainfall of Different Daily Amount, 1919-1985. Climate Change, 19, 319-341. https://doi.org/10.1007/BF00140169

[18] Olesen, J.E. and Bindi, M. (2002) Consequences of Climate Change for European Agricultural Productivity, Land Use and Policy. European Journal of Agronomy, 16, 239-262. https://doi.org/10.1016/S1161-0301(02)00004-7

[19] Onyekwelu, J.C., Mosandl, R. and Stimm, B. (2006) Productivity, Site Evaluation and State of Nutrition of Gmelina arborea Plantations in Oluwa and Omo Forest Reserves, Nigeria. Forest Ecology and Management, 229, 214-227. https://doi.org/10.1016/j.foreco.2006.04.002

[20] Omotosho, J.B. and Abiodun, B.J. (2007) A Numerical Study of Moisture Build-Up and Rainfall over West Africa. Meteorological Applications, 14, 209-225.

https://doi.org/10.1002/met.11 
[21] Ishaya, S. and Abaje, I.B. (2008) Indigenous People's Perception on Climate Change and Adaptation Strategies in Jemma LGA of Kaduna State. Journal of Geography and Regional Planning, 1, 138-143.

[22] Egbe, C.A., Yaro, M.A., Okon, A.E. and Bisong, F.E. (2014) Rural Peoples' Perception to Climate Variability/Change in Cross River State-Nigeria. Journal of Sustainable Development, 7, 25-36. https://doi.org/10.5539/jsd.v7n2p25

[23] Zakari, D.M., Mohammed, A.B., Meduguand, N.I. and Sandra, I. (2014) Impact of Climate Change on Yam Production in Abuja, Nigeria. International Journal of Science, Environment and Technology, 3, 458-472.

[24] Onubuogu, G.C. and Esiobu, N.S. (2014) Trends, Perceptions and Adaptation Options of Arable Crop Farmers to Climate Change in Imo State, Nigeria: A Logit Multinomial Model Approach. Scholarly Journal of Agricultural Science, 4, 370385.

http://www.scholarly-journals.com/SJASISSN2276-7118c2014Scholarly-Journals

[25] Efe, S.I. and Ojoh, C.O. (2013) Spatial Distribution of Malaria in Warri Metropolis. Open Journal of Epidemiology, 3, 118-124. https://doi.org/10.4236/ojepi.2013.33018

[26] Efe, S.I. and Ojoh, C. (2013) Climate Variability and Malaria Prevalence in Warri Metropolis. Atmospheric and Climate Science, 3, 132-140. https://doi.org/10.4236/acs.2013.31015

[27] Weli, V. and Efe, S. (2015) Climate and Epidemiology of Malaria in Port Harcourt Region, Nigeria. American Journal of Climate Change, 4, 40-47. https://doi.org/10.4236/ajcc.2015.41004

Submit or recommend next manuscript to SCIRP and we will provide best service for you:

Accepting pre-submission inquiries through Email, Facebook, LinkedIn, Twitter, etc. A wide selection of journals (inclusive of 9 subjects, more than 200 journals) Providing 24-hour high-quality service User-friendly online submission system Fair and swift peer-review system Efficient typesetting and proofreading procedure Display of the result of downloads and visits, as well as the number of cited articles Maximum dissemination of your research work

Submit your manuscript at: http://papersubmission.scirp.org/ Or contact ajcc@scirp.org 